to normal conditions can be based on the character of the past winter. Another discouraging feature is that the deficiency of rainfall is equally well marked over a large part of Europe. The immediate cause of the deficiency is the abnormal frequency and persistence of anticyclones over the area affected, combined with a displacement northwards of the tracks of the eastward-moving depressions with their attendant rain; but in the absence of any clue to the cause of these abnormal features of the general circulation of the atmosphere, their duration cannot be predicted.

\section{Sky Survey by the Schmidy Telescope at Palomar}

A PROJECT of photograshing the heavens has been announced by tod Aational Geographic Society, Washington, 1 which is sponsoring the scheme, and by the Mt. Filson-Palomar Observatories, which will carry but the programme, and will be known as the Natiohal Geographic Society-Palomar Observa ory Sky Survey. The main work will be done by the 1 -in. Schmidt telescope on Mt. Palomar, and the fies photographs will be taken on July 19, weather permitting, on which night a ceremony will be held in the Schmidt dome. It is expected that the work will be completed in 1953, when three-quarters of the sky out to an average distance of 300 million lightyears will have been photographed. Unusual phenomena recorded by the Schmidt telescope will be studied more intensively later by the "pin-pointing instrument of maximum penetration"-the 200-in. giant at Palomar. Virtually identical exposures of each area will be made by using both blue and red filters to permit comparisons of the widely different pictures obtained in the different colours. When completed, the Survey will record about 500 million stars and perhaps 10 million extra-galactic nebulæ. The "Sky Atlas" which includes this survey will be the equivalent of about twenty large volumes, and it is hoped that the Atlas can be produced at a cost of 2,000 dollars a copy. These will be supplied at cost price to observatories, astronomers, and higher educational institutions throughout the world "to advance the cause of human knowledge". The relatively low cost of production is due to the generous financial assistance rendered by the National Geographic Society. This Survey will prove invaluable as a research guide for the great observatories and will also be an immense boon for the smaller observatories, and for astronomers engaged in theoretical studies, who will be able to use the Survey photographs without recourse to their own telescopic observations. It is believed that the results will be an astronomical bible for at least a century to come.

\section{American Geologists for British Colonial Develop- ment}

REFERENCE was made in Nature of May 28 to the proposed recruitment of American geologists for service in various British Colonial geological surveys. It is statg in Economic Geology of May that the Economif Co-operation Administration has undertaken to finance in part the employment of about twent -five geologists, petrographers and chemistassafers for this purpose. The men will be employed by/the U.S. Geological Survey, and it is proposed to rocruit seventeen field geologists, two petrologists, two chemist-assayers and four ground-water geologists. The qualifications suggested are an honours degree in geology with five years professional field experience, and it is hoped that a few men of longer experience will also be attracted. They will be placed in grades 6-8 of the U.S. Geological Survey according to qualifications, so that their salaries will range from about 8,000 dollars a year upwards. The fields in which they will be employed are given as Nigeria, Gold Coast, Sierra Leone, Kenya, Tanganyika, Uganda, Nyasaland, North Borneo and Sarawak, and British Guiana. Recruitment is to be for three years, after which it is expected that British-trained geologists will be available. The measure is intended to be a temporary expedient devised to overcome lack of personnel in the Colonial geological surveys attributed to the interruption of training during the War.

\section{Uganda Society}

ReCEnTLy in these glumns, accounts have been given of the formation of philosophical societies in two British Colonios in Africa. In Uganda there exists such a body which is well established, both in terms of yeays and activity of membership. The Uganda Soglety, a non-racial, cultural and scientific society, yas reborn in its present form in. 1933 through the inspration of Mr. E. J. Wayland, then director of tho Geological Survey, and Mr. (now Sir) Ralph Hone, then attorney-general in Uganda. Its transactions are published in the Uganda Journal (Oxford University Press) and include a range of subjects embracing ethnology, archæology, geology and local history. The Society has sponsored two major publications, namely: "A Guide to the Snakes of Uganda", by Captain C. R. S. Pitman ; and "Uganda Memories", by Sir Albert Cook. Other books are in course of publication. The present membership of this Society, which it is hoped to increase further, is now more than seven hundred. The officers for 1949 are: President, Dr. Goronwy ap Griffith; VicePresident, Rev. Father F. B. Gaffiney; Editor, Mr. W. V. Harris ; Librarian, Mrs. Barbara Saben; Hon. Secretary, Mr. J. Addington; Hon. Treasurer, Mr. C. W. Stuart. The address of the Society is P.O. Private Bag, Kampala, Uganda.

\section{Education in Industry: Topics for Research}

$$
516
$$

IN an interesting fiticle in Further Education (3, No. 1 ; June Aygust, 1949), Dr. P. Dunsheath, the chairman of British Association for Education in Industhy and Commerce, discusses some of the probleres wlidh have arisen as the result of the growth of dication in industry. When considering the range of dbility, outlook and intelligence among individuals, Dr. Dunsheath indicates that considerable research should be done on the basis of selection for technical courses. Then, remembering that the people affected by education and training in industry are of all ages and positions, he suggests that the problem of how far industrial organisation should concern itself with educational facilities for employees already well established should also be resolved.

Among other questions raised by the author are the following. Should the practical training of engineering students precede a full-time course at a university or technical college, or should it follow the academic course on entry into industrial employment, or should periods of practical work be interposed during the academic years in the form of vacation or sandwich courses? Is it right for a young man destined to become a draughtsman or a designer to spend years at the bench becoming a skilled fitter? Can education be planned for cooperation? To what extent can arts graduates compete with science graduates for the senior posts in industry ? Is management within the next decade 
going to be able to undo the harm done by tradeunion indoctrination of suspicion of the employer among the rank and file? And, finally, will control in industry be in the hands of men of high mental calibre, or of those with political power, irrespective of parsonal suitability?

\section{Yoül 8 Workers in Industry}

THE annual repont of the London Regional Advisory Council for Youth fonployment for 1948 contains a review of legislation introduced during the year to improve the nivitions of young workers in industry. This include the Employment and Training Act, under wetch local responsibility for the youth employmext service will be placed exclusively in the hands of ilcal education authorities; the National Insurancel Act, which lowered the age at which young people can claim unemployment insurance benefit and increased both the rate of contribution and the rate of benefit; and the Factories Act, which provides medical supervision for all young people under the age of eighteen employed in factories, in building and civil engineering and in shipbuilding. The report also contains a statement of the views of the youth employment officers of the London area on the effects of the additional year in school which followed the raising of the school-leaving age from fourteen to fifteen. There was a general improvement in physique, and most boys and girls of fifteen were much more decided as to their choice of job than their fourteen-year-old predecessors had been. So far as some of the boys are concerned, however, the tendency to approach work more seriously is struggling against a sense of frustration caused by the prospect of call-up for military service. Copies of the report may be obtained from H.M. Stationery Office, price $4 d$.

\section{Photographic Unit of the Royal Society of Medicine}

THE photographic unit which the Royal Society of Medicine established, thanks to the generosity of the Rockefeller Foundation, is approaching completion of its shor -term programme of rehabilitation of medical librar es which have suffered owing to the War. By the t/me this work is completed, some 150 libraries will bave received assistance in this way, and 12-13,000 vflumes (chiefly on film) will have been distributed. Further assistance of this kind can be given in/return for payment, with, of course, the agreemgnt of the publishers, who have very generously co-opgrated in the work now drawing to a close. This unit, equipped as it is for all kinds of scientific photography, is now able to undertake work for Fellows of the Society and other men of science. The range of activities covers the preparation of film strips and lantern slides (both standard and miniature), reducing X-ray negatives and making positive images from them, photography of patients and specimens, enlargements and also colour photography. All this work is, of course, undertaken in return for payment; but the fees charged are fixed on a nonprofit making basis. Fellows of the Society receive the service at reduced fees, since they support the Society by their annual subscriptions. The work has been developed for the past two months, and considerable interest has been evoked, not only because of the high quality of the work done, but also because the Royal Society of Medicine, in setting up this unit, is making a very practical contribution to the ancillary services needed by a high proportion of the members of the medical profession. The services outlined above are available to all concerned with sciences allied to medicine, as well as to those dealing with specifically medical subjects. Those interested should communicate with the Secretary, Royal Society of Medicine, 1 Wimpole Street, London, W.l.

\section{Teaching Social Biology}

In the third of the series of occasional papers produced by the Mritish Social Hygiene Council, Miss E. Wd for makes a well-validated plea that social biglogt should form part of the curriculum for the rainfirg of all teachers and should not be left for the attention of the specialist alone. In teachers' trainfing courses the curriculum is traditionally divided into various branches such as principles of education, psychology, history of education and hygiene, and from each of these the social biologist could extract some part which could reasonably be included in a social biology course. This social biology course would develop within the existing course known as health education or hygiene, and, besides studying the functional aspects of the child in order to consolidate positive standards of health, would also consider the child in relation to its environment and society. Miss Watson then gives details of an admirably integrated syllabus which might be included in the curriculum of a university education department year or the second year of a training college course. The paper, which contains a wisely written preface by Prof. E. J. R. Eaglesham, can be obtained from the Secretary, British Social Hygiene Council, Tavistock House North, Tavistock Square, London, W.C.1, price $1 s$.

\section{Bee Research Asfortation}

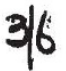

AN organiatiop of British beekeepers which is to be known as the Bee Research Association has recently opres into being, with the object of promoting reseafch on beekeeping and allied subjects by enablint beekeepers and others interested to give fipencial support to the investigations being carried out $y$ " beekeepers under the auspices of the British Beekeepers' Association. The Association, besides promoting research among beekeepers, hopes to be able to help individual investigators with guidance and suggestions, and by putting them into touch with other individuals working on similar problems. It is also proposed to prepare a bibliography and, where possible, abstracts of all original scientific papers relating to bees, honey, etc., for the benefit of members. It is understood that, so far, a bibliography containing about ten thousand references to papers published up to the year 1933 has been prepared. Further information can be obtained from the Honorary Secretary, Bee Research Association, Ltd., 330-331 Salisbury House, London Wall, London, E.C.2.

\section{University of/Aberdeen}

DURING the graduation ceremonies at the University of Aberdeen on July 8 and 9, the honorary degree of LL.D. was conferred on Prof. E. G. R. Tayloy, emeritus professor of geography in the Uniyersity of London. The degree of Ph.D. was conferred on the following, for the theses named: N. A. Bowen, "The Theory of Functions Analytic in an Angle and the related Tauberian Theory of Integral Functions"; J. D. Burnett, "The Photopolymerization of Vinylidene Chloride"; W. Eastwood, "An Experimental Investigation of Engineering Problems in Water, Sand and Silt with special reference to Scale Model Technique"; S. Jamieson, "Clostridium 